\title{
Promoting Students' Critical Speaking Skill through Plus-Minus-Interesting (PMI) Strategies: A Case Study of Indonesian Junior High Schools
}

\author{
SRI SETYARINI \\ Faculty of Language and Literature Education, \\ Universitas Pendidikan Indonesia, Indonesia \\ setyarini.english@upi.edu \\ GIN GIN GUSTINE \\ Faculty of Language and Literature Education, \\ Universitas Pendidikan Indonesia, Indonesia \\ SRI HARTO \\ Faculty of Language and Literature Education, \\ Universitas Pendidikan Indonesia, Indonesia \\ AHMAD BUKHORI MUSLIM \\ Faculty of Language and Literature Education, \\ Universitas Pendidikan Indonesia, Indonesia
}

\begin{abstract}
Initiated from in-depth observations on the performance of English teachers at junior high school level, this study analysed teachers' ways of integrating teaching materials and implementing learning strategies that empowered critical thinking frameworks. A case study design was employed to investigate how Plus-Minus-Interesting (PMI) learning strategies in telling daily life stories improved students' critical speaking skill (CSS) and to identify the constraints faced by the teachers in implementing PMI learning strategies to overcome their teaching problems. Six English teachers from different junior high schools in North Bandung, Indonesia and their students were recruited as subjects of this study. Classroom observation, in-depth interviews and some relevant documents were administered to collect the data. The data were then described, coded, categorised, and analysed to answer the research questions. The results of observations indicate that PMI learning strategies in daily life stories were executed in three stages, including the opening, core, and closing. These stages were performed through several main activities, from brainstorming to playing games, from storytelling to doing a focused-group discussion, and from story mapping to evaluating. In addition, the results of interviews and documents analysis show that this learning model could promote students' enthusiasm in the learning activities and the students were able to convey ideas by referring to their daily problems exposed in the contents of daily life stories.
\end{abstract}

Keywords: critical speaking; daily life stories; junior high school students; PMI learning strategies; storytelling

\section{INTRODUCTION}

Critical thinking (CT) is a pedagogical process that should be nurtured (Idek \& Othman, 2019) along students' development through both formal schooling and non-formal thinking (Sellars et al., 2018). Students should be provided with some opportunities to think critically through sharing of opinions (Sanpatchayapong, 2013), conveying argumentation and making evaluation (Tuzlukova et al., 2017) which do not always make teachers pleased (Spark, 2013). Besides, CT should also be integrated in their school subjects from science to finance (GarciaCorral et al., 2020) to language (Akatsuka, 2019; Hasibuan \& Samosir, 2017; Kulamikhina et al., 2020; Ramezani et al., 2016). It is due to the notion that CT, implemented by students in their daily activities, is actually valuable to drive students to be skilful, creative (Sharma et al., 2020), and sensitive individuals who are responsive to potential problems found in their daily life (Larson \& Miller, 2011). CT skills have indirectly educated students to become independent members of community as problem solvers and decision makers (Harizaj \& 
Hajrulla, 2017; Nikijuluw \& Puspitasari, 2018; Sharma \& Priyamvada, 2017) in a variety of problems (Al-Khatib, 2012; Hayes \& Devitt, 2008). CT skills are very crucial for students to identify, evaluate, and determine attitudes towards problems faced in their daily life. An example is, for instance, an issue of environment due to poor waste management (Greiff et al., 2014; Van Merrienboer, 2013).

Basically, CT skills are part of the higher order thinking skills (HOTS) categorised into three focusing primarily on transfer, terminology, and problem solving (Brookhart \& Bronowicz, 2010). The most common HOTS approach is proposed by Krathwohl and Anderson (2001, cited in Brookhart \& Bronowicz, 2010). The meaning of learning as a transfer, for instance, requires a high level of thinking to result in more meaningful outcomes. This opinion supports Krathwohl (2002) for arguing about the development of cognitive dimensions and revising Bloom's taxonomic cognitive processes (Bloom, 1956) from remembering, understanding, applying, analysing, evaluating to creating. However, among those levels, only three levels (analysing, evaluating, and creating) were used in this study (Bloom, 1956; Krathwohl, 2002).

The above explanation has indicated that HOT refers to one's ability to maximise the content of texts into one's daily life. In the context of Indonesia, the teaching of English as a foreign language (EFL) should provide students with a holistic nature of reading from vocabulary, grammar, to discourse (texts) conditioning the students to get involved in the contents of texts through playing their roles as actors in stories. By doing so, students felt that they were parts of stories based on their own understanding (Krathwohl, 2002). The process of maximising the use of texts in students' daily life was very much influenced by several factors. Burchinal and Forestieri (2011) explained that a microsystem plays an important role for home and child-care environments, particularly in the acquisition of early literacy skills. In addition, there are many aspects of nurture and classroom instruction that greatly contribute to the development of students' ability to use, decode, and maximise the use of texts.

In addition to the written discourse that has been explored above, as one of language skills, speaking is a process of conveying messages, ideas, and feelings through the use of spoken language (Cameron, 2001; Tarigan, 2008). English speaking skill is intended for the students to make use of language as a communication tool in the context of life. Moreover, English is now a lingua franca used by people in every aspect of life, i.e. economic, social, health, and education (Mansfield \& Poppi, 2012), to mention just a few. The development of students' speaking skills in English subject is, therefore, very important to be achieved. Although the speaking skill is sometimes considered easier than that of writing skill, it can occur naturally (Bowman, 2010) with the frequency of language use. However, changes in learning orientation in the 21 st century (Changwong et al., 2018; Sellars et al., 2018; Tuzlukova et al., 2017) have directed educational goals at every level of education to integrate critical thinking skills (Al-Sharadgahm, 2014) in their school subjects. So, it is important for teachers to develop teaching materials and task assignments (Harizaj \& Hajrulla, 2017) that are not only oriented to language skills but also integrated CT skills (Akatsuka, 2019) in their language learning.

Given the importance of English as a lingua franca in Indonesia, teaching English needs to be done at an earlier age, for instance, from the elementary school level. This is relevant to what is shared by Jianbin and Jiayan (2010) and Wang and Vasquez (2012) that the teaching of English needs to be oriented earlier in order to provide students with some competencies to communicate and compete with people in a global world. Unfortunately, with regard to the 2013 Curriculum, Ministry of Education and Culture of the Republic of Indonesia (Kemdikbud, 2013), English is officially introduced to students at junior high school level. According to the curriculum, one of the objectives of learning English is to achieve the goal of communication in a social context to build students' character education for both academic competence and 
social competence. Thus, the patterns of teachers' approaches in teaching English are very important since students at junior high school have unique characteristics to produce optimal learning outputs. The characteristics of junior high school students are easily stimulated by dynamic, challenging and fun activities (Harklau, 2007). Therefore, students will find themselves interested in learning when teachers deliver their lessons using fun, non-boring, and contextual ways that are relevant to their daily life.

However, until recently, this issue seems not to have gained sufficient attention from stakeholders (policy makers, parents, teachers, and society). Some factors were investigated in the current studies related to CT and HOTS. Setyarini (2016) identified some teachers' challenges in teaching and promoting $\mathrm{CT}$ such as difficulties, lack of experience, low beliefs and insufficient teaching sources and support. Teachers claimed that they had no ideas of how to promote $\mathrm{CT}$ in language learning. Learning strategies were considered as one of teaching difficulties since they were difficult to get appropriate models for teachers who have successfully implemented CT-based learning. Some other teachers recognised its difficulty, particularly in assessing students through using ordinary scoring practices in the test. In other words, they considered that CT assessment was not a standardised one since there was no single answer given as their reference (Setyarini, 2016). In addition, the teachers were considered to be too pessimistic to promote students' CT since they cannot communicate well in the target language. As a consequence, the students found it difficult to share ideas, reasons, and arguments (Setyarini et al., 2018). It automatically led to misconceptions in teaching CT which overlapped with the teaching of language skills. The teachers assumed that accommodating students to think critically was complicated. These problems implied that teachers still have low beliefs in the urgency and essentials of CT in language learning and misconceptions about its principles (Setyarini et al., 2018).

To prove the importance of teaching CT to students, some studies have been conducted. Yen and Halili (2015) highlighted that CT aimed to shape students' habits since they gained more exposures of being critical during their learning. Hidayat et al. (2020) found that critical thinking should be integrated in language learning since students were accustomed to giving their perspectives, comments, and arguments directed to support social justices. By doing so, students eventually possessed more social awareness. In line with this, Setyarini and Narita (2017) claimed that teachers' strategies had an important role in framing students' critical thinking. Various strategies have been implemented by teachers in English language teaching. However, the strategies that have been implemented so far are not integrated with critical thinking skills. These skills are considered important by students to deal with increasingly complex problems requiring students to appropriately handle the problems (Yen \& Halili, 2015). For this reason, critical thinking skills do not only teach students to identify problems and find solutions (Sanpatchayapong, 2013), but also make right decisions to critically solve problems through analysis, evaluation, and determination (Larson \& Miller, 2011).

Furthermore, giving open-ended questions, a characteristic of CT, can stimulate students to compare and contrast objects and ideas. Analogical reasoning is another learning strategy aimed at promoting students' critical thinking. It expands students' knowledge to relating one case to another, supported by their critical opinions. Apart from classroom interactions, critical thinking could also be taught through outdoor education (Setyarini et al., 2020) through critically observing the surrounding objects. Students were aroused to describe their observation results in the form of critical descriptive writing in terms of producing authentic descriptions derived from their critical views. In terms of CT assessment and evaluation, teachers also experience some constraints in constructing assessment for students. Setyarini and Narita (2017) found that assessments constructed by teachers have not demonstrated critical thinking-based assessment principles. It was indicated from the answers 
to the questions which were explicitly written in the text. More specifically, students' answers were taken from the given text and they were not requested to give their own reasons.

In response to the above problems encountered by English teachers, Plus-MinusInteresting (PMI) earlier initiated by De Bono (1982) through the six thinking hats model, followed by some further studies (Kivunja, 2015; Sharma \& Priyamvada, 2017; Nikijuluw \& Puspitasari, 2018; Sharma et al., 2020) in English as a Foreign Language (EFL) learning contexts are considered relevant to be an innovative strategy to promote the students' critical thinking skills. In the context of teaching critical speaking skill, it can be done through telling daily life stories since these types of stories are very familiar with the students' daily life experiences. Through telling daily life stories, the students are expected to actively engage themselves in the English learning through associating their prior knowledge and experiences in their daily life to the stories they are learning in the classrooms. This research, therefore, aims to provide more practical and comprehensive input for language teachers, parents, and policymakers to introduce critical thinking skills in English learning, particularly to junior high school students through both written and spoken practices. It also revealed the obstacles experienced by both teachers and students in the implementation of PMI strategies and the solutions to overcome them.

\section{METHODOLOGY}

\section{RESEARCH DESIGN}

Through the implementation of a qualitative method with case study design (Hancock \& Algozzine, 2006; Yin, 2018), this research aims to explore PMI learning strategies applied in the storytelling of daily life stories to improve junior high school students' critical speaking skill (CSS). This design is also made to develop teachers' teaching skills and provide them with a better role to engage with their students (Burns \& Grove, 2010; Sharma et al., 2020). It is assumed that junior high school students' critical thinking skills have not been integrated in school lessons and it can be optimally developed through English language teaching activities. A study by Setyarini (2016) shows that students' critical thinking skills are relatively low, as perceived through the essence of reasoning in their answers provided for teachers' questions in class.

With regard to the implementation of PMI learning strategies, a series of learning processes were generally classified into three stages including opening, core, and closing (Mirawati \& Amri, 2013; Pelenkahu, 2017). Some studies showed how in each of these stages, students were given different assignments by using brainstorming and mind-mapping techniques through PMI-based daily life stories. Teachers provided clear and understandable story samples for their students. The learning activities implemented PMI-based learning strategies through making comparison, categorisation, analysis, and evaluation. The results from past studies provided a glimpse of how PMI strategies were implemented, and the difficulties faced by both the teachers and students.

Some past studies show how materials and learning activities in the classroom follow the PMI principles (De Bono, 1982; Nikijuluw \& Puspitasari, 2018; Sharma \& Priyamvada, 2017; Sharma et al., 2020). As suggested by Emilia (2011), the types of texts to be implemented in daily life storytelling, among others, were recount, descriptive, and procedural texts. The materials, media, and learning stages were arranged by teachers on the basis of PMI principles. At this stage, a particular problem was compared, categorised, analysed and evaluated by students with the facilitation of teachers through examining the strengths and weaknesses in order to come up with a conclusion and a decision. It was mainly intended for teachers to find out how PMI strategies were implemented and how they gave positive impact on the 
improvement of students' critical speaking skills in English (Akatsuka, 2019; Mirawati \& Amri, 2013).

\section{RESEARCH SITE AND PARTICIPANTS}

Six junior high schools consisting of four public and two private schools located in North Bandung, West Java, Indonesia were purposively selected to voluntarily participate in this case study (Creswell, 2012; Gay et al., 2006). The selection of these schools was mainly based on three reasons, i.e. the schools were close to the university where researchers found it easier to visit the schools; the schools did some collaborative activities with the researchers, particularly in teaching practicum for the undergraduate students; and the researchers did some supervision at the schools for different purposes, i.e. trainings, workshops, conferences and research. The observed learning processes were related to English learning for eighth graders of junior high school using narrative texts as the main materials (Emilia, 2011). The teachers used pure narrative texts in describing legends about a particular area or character, but in PMI learning strategies, it appeared that teachers packed the narrative texts into daily life stories about people's experiences. One of the texts used, for instance, was "My room" which was then packaged by the teachers into a daily life story entitled "Cockroaches attack my room". The selection of this story was based on the suitability and relevance of the story with those of students' characteristics and experiences.

\section{RESEARCH INSTRUMENTS}

The three main research instruments that were used to collect data were classroom observation, interviews with English teachers and students, and relevant documents in the form of lesson plans, students' assignments, and students' written stories. The classroom observation, according to Malik and Hamied (2016), was done to observe behaviours, actions, and communication patterns among the students. The results of the observation should then be written in greater detail and they were documented in observation sheets to make it easier for the researchers to focus on the class. In this context, students' responses and their levels of critical speaking skills were then written in the comments and oral responses that had been earlier provided by the teachers. In addition, other aspects observable by the researchers should also be written in the observation sheets that have been prepared beforehand. Then, during the observation period, the teachers' behaviours were primarily observed to determine whether the principles of PMI learning strategies had been implemented in the teaching activities. Subsequently, the development of students' critical thinking skills, particularly their critical speaking skills could be clearly observed.

Interviews with the English teachers and students were done by implementing the principles of semi-structured interviews (Creswell, 2012; Gay et al., 2006). These were intended to make the teachers and students feel comfortable in answering questions without being worried about telling the truth with regard to their knowledge and experiences in implementing the PMI principles. The interviews were undertaken in two different languages, i.e. Indonesian and English, depending upon the situations faced by them. This interview was aimed at finding out the teachers' opinions about their experiences in the implementation of PMI learning strategies integrated in daily life storytelling and in exploring the challenges faced by the teachers and ways undertaken when implementing the learning strategies. Meanwhile, students' interviews were aimed at eliciting their opinions about the learning processes they followed and their comments on the improvement of critical thinking skills. These interviews also supported the results of classroom observation (Stainback \& Stainback, 1996) to come up with more comprehensive data. 
Relevant documents which include lesson plans, students' assignments and written stories were used as data sources from which the data were collected. This included both written and spoken documents of the students' daily life stories. The stories told by the students was transcribed to identify aspects of critical thinking skills based on the Bloom taxonomy (Anderson et al., 2001) and the principles of thematic analysis (Braun \& Clarke, 2006, 2012, 2014; Clarke \& Braun, 2013, 2018). This instrument included the results of students' performances when communicating with other students and teachers in the form of written works. Responses and arguments made by the students were recorded both in group and individual activities to identify whether the students have demonstrated critical thinking skills in the form of positive, negative, and neutral arguments. These recordings were then investigated, categorised, and presented based on the levels of their critical thinking skills according to the Bloom taxonomy (Anderson et al., 2001). In addition, other relevant documents that were analysed include the lesson plans prepared by the teachers before implementing the learning strategies. Some aspects of the lesson plans were identified to see the learning activities, learning strategies, and assessment. The lesson plans can be used as a reference to see whether or not teachers fully implement the learning activities to achieve the expected research results.

\section{DATA ANALYSIS}

The research data were analysed using several procedures. First, the data obtained from classroom observation in the forms of audio and video recordings were transcribed into written texts. The transcriptions were identified to see the contents of critical thinking skills (CTS) with regard to theories of Bloom taxonomy (Anderson et al., 2001) and to categorise them based on the levels of critical thinking and framework of plus-minus-interesting (PMI). The unnecessary data were reduced to focus on the main points of the study. Meanwhile, the interview data were transcribed and categorised into tables based on the main themes found in the research data. Subsequently, the data from relevant documents about the students' daily life stories were identified using PMI strategies and higher order thinking (HOT) theories.

The data were then analysed using thematic analysis (TA) developed by Braun and Clarke $(2006,2012,2014)$ and Clarke and Braun $(2013,2018)$ through both data- and theorydriven approaches (Braun \& Clarke, 2006, 2012; Maguire \& Delahunt, 2017; Kiger \& Varpio, 2020; Tuspekova et al., 2020). The data were classified into several themes according to the six stages in the implementation of TA - getting familiar with data, making initial codes, finding the themes, making reviews on the themes, giving names to the defined themes and making the report. In more specific ways, macro and micro examples were given to provide details on how to deal with the themes and review them (Kiger \& Varpio, 2020; Walsh et al., 2019). Based on the theories of TA, therefore, this particular research has come up with main themes related to the development of critical thinking, the teachers' strategy in promoting students' critical speaking skill through PMI, and constraints faced by both teachers and students in the implementation of PMI strategy.

\section{RESULTS AND DISCUSSION}

Based on selective data analysis drawn from classroom observation, interviews with English teachers and students, and relevant documents obtained from teachers' lesson plans, students' assignments, and students' written stories, three central-themes were identified. Through the implementation of thematic analysis using both bottom-up (inductive) approach and top-down (deductive) approach (Braun \& Clarke, 2006, 2012, 2014; Clarke \& Braun, 2013, 2018), the 
three themes are presented here as the main findings of this research. These themes include teachers' strategies to promote students' critical speaking, techniques in building students' critical thinking, and the constraints faced by both teachers and students in the implementation of PMI strategies. These findings are presented in the following sections accompanied with the discussions.

\section{TEACHERS’ STRATEGIES TO PROMOTE STUDENTS’ CRITICAL SPEAKING SKILL}

The first theme deals with teachers' strategies (TSs) implemented by six English teachers (ETs) from six different junior high schools (ET1, ET2, ET3, ET4, ET5, \& ET6) to promote students' critical speaking skill through the PMI strategy. The six teachers did English teaching in their own schools and implemented different numbers of TSs from one teacher to another. There were fifteen TSs derived from the teachers' practices in their effort to improve students' critical speaking skill (CSS). English teacher-3 (ET3), for instance, implemented 12 different TSs $(80 \%)$ out of 15 TSs, except three of them, i.e. TS-3, TS-5, and TS-13. This number is then followed by ET5 with 11 TSs (73\%), ET1 and ET4 with eight TSs each (53\%), ET6 with seven TSs (47\%), and ET2 with six TSs (40\%). Details of the teachers' strategies to promote students' critical speaking skill are presented in Table 1 below.

TABLE 1. Teachers' strategies to promote students' critical speaking skill

\begin{tabular}{|c|c|c|c|c|c|c|c|}
\hline No & Teachers' strategies in the implementation of PMI & ET1 & ET2 & ET3 & ET4 & ET5 & ET6 \\
\hline 1 & $\begin{array}{l}\text { Telling stories attractively through appropriate facial expressions, body } \\
\text { movement, and intonation to bring students into contexts of stories. }\end{array}$ & $\sqrt{ }$ & - & $\sqrt{ }$ & $\sqrt{ }$ & $\checkmark$ & - \\
\hline 2 & $\begin{array}{l}\text { Simplifying content of stories to meet students' characteristics and } \\
\text { language ability to ease them understand the stories. }\end{array}$ & - & $\checkmark$ & $\checkmark$ & - & $\checkmark$ & - \\
\hline 3 & $\begin{array}{l}\text { Encouraging students to imagine similar stories happening in their life } \\
\text { to promote their critical thinking. }\end{array}$ & $\checkmark$ & $\checkmark$ & - & - & $\checkmark$ & $\checkmark$ \\
\hline 4 & Exposing students to think critically using open-ended questions. & $\checkmark$ & - & $\checkmark$ & $\checkmark$ & $\checkmark$ & - \\
\hline 5 & $\begin{array}{l}\text { Offering students' opportunities by giving alternative answers toward } \\
\text { critical questions. }\end{array}$ & $\checkmark$ & $\checkmark$ & - & $\checkmark$ & - & $\checkmark$ \\
\hline 6 & $\begin{array}{l}\text { Exposing analytical, evaluative, and creative thinking based on PMI in } \\
\text { storytelling classroom. }\end{array}$ & - & - & $\checkmark$ & - & $\checkmark$ & - \\
\hline 7 & Providing scaffolding to students in response to case-based problems. & $\checkmark$ & $\checkmark$ & $\checkmark$ & $\checkmark$ & $\checkmark$ & $\checkmark$ \\
\hline 8 & $\begin{array}{l}\text { Empowering students to get used to giving their opinions, arguments, } \\
\text { and reasons. }\end{array}$ & $\checkmark$ & - & $\checkmark$ & $\checkmark$ & - & $\checkmark$ \\
\hline 9 & $\begin{array}{l}\text { Exploring students' point of views in responding to PMI cases in the } \\
\text { form of stories. }\end{array}$ & - & $\checkmark$ & $\sqrt{ }$ & $\checkmark$ & $\checkmark$ & $\checkmark$ \\
\hline 10 & Showing moral lessons from stories to build students' social awareness. & - & - & $\checkmark$ & - & - & $\checkmark$ \\
\hline 11 & $\begin{array}{l}\text { Promoting students' confidence in speaking English through PMI } \\
\text { strategies. }\end{array}$ & $\checkmark$ & - & $\checkmark$ & - & $\checkmark$ & - \\
\hline 12 & $\begin{array}{l}\text { Training students to be responsible for their ideas, arguments, reasons, } \\
\text { and comments in any context of communication. }\end{array}$ & $\checkmark$ & $\checkmark$ & $\checkmark$ & - & - & - \\
\hline 13 & $\begin{array}{l}\text { Checking students' understanding with regard to their critical } \\
\text { perspectives in learning. }\end{array}$ & - & - & - & $\checkmark$ & $\checkmark$ & $\checkmark$ \\
\hline 14 & $\begin{array}{l}\text { Composing more child-friendly stories related to students' world and } \\
\text { experiences. }\end{array}$ & - & - & $\checkmark$ & - & $\checkmark$ & - \\
\hline \multirow[t]{3}{*}{15} & $\begin{array}{l}\text { Creating students' independence in speaking critically based on their } \\
\text { learning experiences. }\end{array}$ & - & - & $\checkmark$ & $\checkmark$ & $\checkmark$ & - \\
\hline & Total & 8 & 6 & 12 & 8 & 11 & 7 \\
\hline & Percentage & $53 \%$ & $40 \%$ & $80 \%$ & $53 \%$ & $73 \%$ & $47 \%$ \\
\hline
\end{tabular}


In this particular case, as an example, English teacher-1 (ET1) and English teacher-4 (ET4) provided students with open-ended questions (Teachers' Strategies-4, TS-4) to direct and encourage students to achieve critical thinking skills. This practice indicated that the openended questions were identified to help promote students' explicit expression of ideas (Tuspekova et al., 2020). However, before moving forward to critical questions, based on the results of observation (Obs.), closed-ended questions were also important to motivate students to engage in answering teachers' questions and to take part in classroom discussion (Obs-ET1, ET3, ET4 \& ET5). It means that the students should be nurtured (Idek \& Othman, 2019) through processes along with the students' development obtained from both formal schooling and non-formal thinking (Sellars et al., 2018) derived from students' real-life experiences (TS3). Also, the real-life experiences (TS-3) has built students' critical thinking (CT) and encouraged them (Almalki, 2019; King et al., 2010) to see and evaluate different phenomena from various point of views (De Bono, 1982; Nikijuluw \& Puspitasari, 2018; Sharma \& Priyamvada, 2017; Sharma et al., 2020). In addition, with regard to Teachers' Strategies-12 (TS-12), students were provided with guidance in implementing higher order thinking (HOT) skills by providing logical arguments and reasons (Brookhart \& Bronowicz; 2010; Tuzlukova et al., 2017; Warliati et al., 2019) to support their opinions and presenting relevant evidence to support the answers (Obs-ET1, ET2 \& ET3).

\section{TEACHERS’ TECHNIQUES IN BUILDING STUDENTS’ CRITICAL THINKING}

The second theme emerging from the classroom observation data is the teachers' techniques in building students' critical thinking skills (CTSs). The second theme was aimed at portraying teachers' techniques and main activities in building students' critical thinking which were then divided into three stages as suggested by Mirawati and Amri (2013) and Pelenkahu (2017) including pre-activity, whilst-activity, and post-activity. This study adapted some theories of learning stages proposed by Mirawati and Amri (2013) and Pelenkahu (2017) covering the opening, core, and closing stages.

Table 2 presents the opening (preliminary) stage which covers the techniques of brainstorming, mind-mapping, showing pictures, singing together and playing games. The brainstorming technique, for instance, was applied by teachers in the early part of learning to introduce learning topics to students at the scheduled meetings. The brainstorming was done through mentioning the title of the stories, characters, and settings. In accordance with the results of teachers' interviews, brainstorming was very important to prepare students to engage in the learning process (Wilson, 2016). Meanwhile, classroom observation also identified that PMI strategies in daily life storytelling activities were carried out by the teachers through several activities, such as analysing, scoring, and concluding (Sharma \& Priyamvada, 2017). The brainstorming process helped students to gradually follow the learning process before entering the core materials. With brainstorming techniques, students were stimulated to explore ideas related to knowledge they knew about the materials being discussed. It indicated that brainstorming was focused on developing students' ideas and preparing students to engage in the learning topics (Al-Khatib, 2012). Details of teachers' techniques in the opening stage are presented in Table 2. 
TABLE 2. Teachers' techniques and main activities in the opening stage

\begin{tabular}{|c|c|c|}
\hline Stage & Techniques & Main activities \\
\hline \multirow{5}{*}{$\begin{array}{l}\text { Opening } \\
\text { (Preliminary) stage }\end{array}$} & 1. Brainstorming & - Mentioning the title of the stories, characters, and settings. \\
\hline & 2. Mind-mapping & $\begin{array}{l}\text { - Drawing a tree diagram and asking students to fill in each branch } \\
\text { with new vocabularies. }\end{array}$ \\
\hline & 3. Showing pictures & $\begin{array}{l}\text { - Asking students to focus on the stories based on the picture series. } \\
\text { - Identifying clues from each picture card. } \\
\text { - Playing pictures games. }\end{array}$ \\
\hline & 4. Singing together & $\begin{array}{l}\text { - Attracting students to follow lessons through singing together. } \\
\text { - Practicing pronunciation through singing. } \\
\text { - Making dialogues through singing. } \\
\text { - Completing missing vocabularies. }\end{array}$ \\
\hline & 5. Playing games & $\begin{array}{l}\text { - Recognising new vocabularies after catching the cards. } \\
\text { - Matching vocabularies they got with the chosen characters of the } \\
\text { story. } \\
\text { - Classifying the cards based on the settings of the story. } \\
\text { - Introducing topics to discuss in the learning process. } \\
\text { - Gradually following the learning before entering the core learning } \\
\text { activities. } \\
\text { - Stimulating students to explore ideas dealing with their own } \\
\text { experiences. } \\
\text { - Developing students' ideas and preparing them to engage in the } \\
\text { topics of their learning. }\end{array}$ \\
\hline
\end{tabular}

Based on Table 2, students' engagement is very important (Wilson, 2016) as it is indicated in the fifth technique of playing games presented in the opening stage. The games directed the students from recognising new vocabularies, matching the vocabularies they got with the chosen characters of the story, classifying the cards based on the settings of the story, introducing topics to discuss in the learning process, following the process before entering the core learning activities, stimulating students to explore ideas dealing with their own experiences, to developing students' ideas and preparing them to engage in the topics of their learning (Wilson, 2016). Through similar processes, with their own unique characteristics, the other teachers' techniques, i.e. mind-mapping, showing pictures, and singing together, could be done to encourage students to engage in other main activities in order to build students' critical thinking through the above five techniques. Before arriving at the core materials, the teachers also gave students some time to get to know some main vocabularies by playing a guessing game. The gestures performed by the teachers were intended to attract students' attention. Students were challenged to solve puzzles to build their enthusiasm in responding to teachers' questions. One of the students (Student-1), as indicated in quotation [1], shared an experience of learning new vocabularies during an interview with the teacher.

[1] "Belajar kata-kata baru seru dalam bahasa Inggris. Kalau bu guru kasih skor jadi pengen jawab lagi terus. Seru nambah kosa kata baru jadi bisa dipakai untuk ngomong bahasa Inggris. Biasanya kan dari game juga suka nemu kata kata baru." ("It is exciting to learn new vocabularies in English. The scores provided by the teacher have encouraged me to answer questions again and again. It's fun to pick up new vocabularies to speak up in English. Also, I usually get new vocabularies from playing games"). (Int-Student-1).

In the core stage, four techniques implemented by the teachers, among others, were storytelling, role-playing, asking some open-ended questions, and doing a focused-group discussion. These techniques were believed to promote explicit expressions of students' ideas (Tuspekova et al., 2020). Each technique has a different number of activities ranging from two to eight. Storytelling as the first technique presented in the core stage, for instance, consisted of four main activities including the expression of words through gestures, presentation of contents of stories followed by body movements, description of events using facial expressions, 
and the provision of discourse markers which referred to the generic structure of the stories. The other three techniques, i.e. role-playing, asking some open-ended questions, and doing a focused group discussion, and their main activities are clearly indicated in Table 3 . A modelling process, as indicated in the third technique, is done to provide students with sufficient exposures in relevant contexts and to encourage them to express opinions, arguments, and ideas relevant to the topics of discussion supported by data, claims, and warrant (Brunner, 2011; Toulmin, 2003). Teachers' techniques and main activities implemented in the core stage are presented in Table 3 in the following.

TABLE 3. Teachers' techniques and main activities in the core stage

\begin{tabular}{|c|c|c|}
\hline Stage & Techniques & Main activities \\
\hline \multirow[t]{4}{*}{ Core stage } & 1. Storytelling & $\begin{array}{l}\text { - Expressing words appropriately through their gestures. } \\
\text { - Verbally conveying contents of story accompanied by body } \\
\text { movements. } \\
\text { - Describing events of the story through facial expressions. } \\
\text { - Putting the discourse markers according to the generic structure } \\
\text { of the stories. }\end{array}$ \\
\hline & 2. Role-playing & $\begin{array}{l}\text { - Asking students to play roles as actors to represent the } \\
\text { characters of the story while the teacher was narrating the story. } \\
\text { - Making a dialogue according to their role. }\end{array}$ \\
\hline & $\begin{array}{l}\text { 3. Asking some } \\
\text { open-ended } \\
\text { questions }\end{array}$ & $\begin{array}{l}\text { - Conducting a modelling process through the provision of } \\
\text { sufficient exposures for the students through the use of } \\
\text { contextual language. } \\
\text { - Modelling the students using the patterns of open-ended } \\
\text { questions. } \\
\text { - Identifying the grammatical patterns in making open-ended } \\
\text { questions. } \\
\text { - Making open-ended questions in groups. } \\
\text { - Doing a question and answer session in a group. } \\
\text { - Practicing to argue other groups ideas and giving comments. } \\
\text { - Treatly helping the students to understand the story. } \\
\text { peaching moral-lessons from the story based on the students, } \\
\text { point of views. }\end{array}$ \\
\hline & $\begin{array}{l}\text { 4. Doing a focused- } \\
\text { group discussion }\end{array}$ & $\begin{array}{l}\text { - Identifying the use of grammar, appropriate vocabulary, } \\
\text { accurate pronunciation and expressions to deliver the story } \\
\text { attractively. } \\
\text { - Justifying the other groups' performance. } \\
\text { - Exchanging ideas and doing peer-correction. } \\
\text { - Drawing a conclusion and making a reflection. }\end{array}$ \\
\hline
\end{tabular}

One of the narrative texts used in the learning process was entitled "Cockroaches attack my room". It was modified by the teachers to be presented to students by using a variety of media, such as pictures and short videos. The modification of daily life stories was aimed at improving students' critical speaking skills, identifying the obstacles and constraints faced by both teachers and students, and finding out solutions of the identified problems to obtain optimum learning achievements. The students' critical speaking skills required awareness and well preparedness of teachers (Sanpatchayapong, 2013) to deal with learning materials, relevant learning strategies and appropriate evaluation tools to obtain optimum learning achievements (Limbach \& Waugh, 2010). Through the learning techniques and the main activities that have been identified by the teachers, in this particular research context, through an integration with the daily life stories, it was found out that PMI strategies (Sharma \& Priyamvada, 2017; Sharma et al., 2020) can be carefully determined as an interesting learning alternative for junior high school students to achieve better ideas through the practices of critical thinking (Portmann \& Easterbrook, 1992). 
Finally, in the closing stage, five techniques applied by the teachers included story mapping, reflecting, modifying stories, retelling stories, and evaluating. These techniques were then followed by main activities to promote students' critical thinking through a series of activities under a certain teachers' technique. For example, story mapping consisted of two main activities, such as writing appropriate vocabularies (clues) below the given pictures, and taking moral lessons considered important through the provision of reasons. Details of the other teachers' techniques and main activities undertaken in the closing stage are presented in Table 4.

TABLE 4. Teachers' techniques and main activities in the closing stage

\begin{tabular}{|c|c|c|}
\hline Stage & Techniques & Main activities \\
\hline \multirow[t]{5}{*}{ Closing stage } & 1. Story mapping & $\begin{array}{l}\text { - Writing appropriate vocabularies (clues) below the given } \\
\text { pictures. } \\
\text { - Taking moral lessons that they considered important and giving } \\
\text { reasons. }\end{array}$ \\
\hline & 2. Reflecting & $\begin{array}{l}\text { - Imagining what, why, and how to be a character of the story based } \\
\text { on their own perspectives. } \\
\text { - Sharing the students' perspectives about the moral lessons in } \\
\text { pairs. } \\
\text { - Positioning themselves based on the analysis toward the } \\
\text { characters, settings, events, problems, and solutions taken from } \\
\text { the story. }\end{array}$ \\
\hline & 3. Modifying stories & $\begin{array}{l}\text { - Modifying the story based on the students' experience. } \\
\text { - Peer-reading and exchanging ideas. } \\
\text { - Peer-correcting. }\end{array}$ \\
\hline & 4. Retelling stories & $\begin{array}{l}\text { - Retelling modified-stories. } \\
\text { - Analogising the modified-story spontaneously. } \\
\text { - Giving overall inputs and comments. }\end{array}$ \\
\hline & 5. Evaluating & $\begin{array}{l}\text { - Applying the moral lessons given in the story in their real-life. } \\
\text { - Nurturing moral lessons in their mindset. }\end{array}$ \\
\hline
\end{tabular}

Based on the descriptions of the three stages above, students' responses and reasons were classified into three categories, Plus (P), Minus (M), and Interesting (I) (De Bono, 1982; Sharma \& Priyamvada, 2017; Nikijuluw \& Puspitasari, 2018; Sharma et al., 2020). In the Plus (P) category, students were required to show positive points and strengths of the decisions they chose. While in the Minus (M) category, students were encouraged to give statements on negative aspects of the choices they made. Finally, in the Interesting (I) category, students were directed to explain further information and arguments on the choices they made. Through indepth interviews (Ints.) with students which were done in Indonesian language (the English translation is provided for readers), students from different schools responded positively to the PMI strategies implemented by the English teachers. Two of the selected responses (IntStudent-2 and Int-Student-3) are quoted in the following ([2] \& [3]).

[2] "Saya sangat suka belajar seperti ini karena saya banyak memiliki kesempatan untuk berpendapat. Ibu guru juga tidak pernah menyalahkan saya ketika saya tidak tahu beberapa kata dalam bahasa Inggris". "I like this kind of learning strategies very much since I have many opportunities to convey my point of views. The teacher never blames me when I do not know some of the English words") (Int-Student-2).

[3] "Menurut saya ceritanya lebih mudah dipahami. Saya tahu siapa saja tokoh yang ada di dalam cerita tersebut. Itu membuat saya paham inti cerita secara keseluruhan". (I think the story is easier to understand. I know who the character of the story is. It makes me understand the main points of the story) (Int-Student-3). 
In the process of PMI implementation, there were a number of constraints encountered by both teachers and students. They were identified from classroom observations revealing that PMI learning strategies were made based on the lesson plans prepared by the teachers. However, observations show that the teachers did not understand the essence of each activity outlined in the lesson plans. The orientation of teaching and learning was also very much influenced by the social and cultural environment with limitations in materials and exposures available outside the class (Xu et al., 2017).

In addition, based on the emerging data collected from both classroom observations and interviews with the teachers and students in their effort of promoting students' critical thinking skills, it was identified that the teachers showed inadequate experiences and knowledge in the implementation of critical thinking skills-based learning. These were the main obstacles in achieving the expected goals. The same idea was demonstrated by Setyarini (2016) and Yen and Halili (2015) who highlighted the importance of teachers' roles in determining the success of critical thinking skills-based learning.

Several indicators emerged were related to (1) the teachers' creativity to adapt and modify the lesson plans to suit the class conditions, students' needs, and students' abilities; (2) the teachers' flexibility to adjust teaching materials to meet the needs and abilities of the students; and (3) the teachers' skills to integrate teaching materials, learning activities, and assessments to have some proper continuity and interconnectedness. These could be seen from the ability of teachers to find alternatives and improvisation when facilitating the learning process. The teachers tended to focus only on providing singing and storytelling activities, but they forgot the essence of thinking skills-based learning and to provide some reasoning priorities. Based on the observations, the teachers did not encourage students to think critically but they only drove them to know and to remember. It was viewed from the ways in which teachers used a translation method to respond to students' questions with regard to unfamiliar words found in the stories. Then, the teachers directly gave answers to the questions through providing the Indonesian translation. This was in contrast with the principles of critical thinking skills-based learning that were supposed to be incorporated in students' learning activities (Anderson et al., 2001).

Due to the long and complex stories provided by the teachers, students at junior high schools found it difficult to understand the stories that were not modified or simplified. This was one of the students' constraints in understanding teachers' full stories without any modification and simplification. Consequently, students were not interested in involving themselves in the learning activities and it was admitted by one of the teachers (ET6) in an interview as indicated in the following quotation ([4]):

[4] "Saya hanya menggunakan cerita dari materi ajar yang sudah tersedia dan saya percaya bahwa itu sudah cukup layak. Selama ini saya sering mengambil teks yang sudah tersedia di buku teks siswa dan saya pikir itu sudah cukup rasanya". ("I only use stories from the available learning resources and I believe that they are adequate for use as learning materials. So far, I often take some texts available in students' textbook and I think they are adequate enough for use [in this class]"). (Int-ET6).

One of the aspects that play an important role in improving students' understanding of the stories provided by the teachers was done through linking the stories with students' experiences and knowledge (Puchta, 2012). If teachers did not fully understand the essence of materials used in critical thinking skills-based learning, the consequences would impact students' understanding of the required material since critical thinking skill is inseparable from teachers' ability to create and make critical thinking skills a culture of learning in the classroom (Coffman, 2013). For that reason, the closer the context delivered to the students' experiences and knowledge, the easier it is for students to compare and contrast them with those of their 
own experiences. In this particular stage, students were directed to have a critical thinking framework through making analysis and evaluation. Providing appropriate and natural contexts that were actually faced and experienced by the students in the teaching materials were, therefore, considered important to be implemented by the teachers. Furthermore, the other important point to note about the unfamiliarity of students with their critical thinking skills, particularly in their speaking skill, was identified. In addition, based on the observation made, students' responses to the open-ended questions, such as "why" and "how" did not show positive results in terms of their arguments and opinions. Most students did not show their active engagement in responding to teachers' questions as they answered "yes or no" without providing further information and arguments that were requested by the teachers.

\section{CONCLUSION}

With regard to the research results presented earlier, some conclusions are drawn here. The teaching of critical thinking skills needs to start from primary and secondary education levels. It requires serious awareness and preparation from teachers, particularly those related to lesson planning, learning implementation, and learning evaluation. These processes require appropriate stages and adequate strategies from teachers to adapt several theoretical frameworks on critical thinking skills. PMI strategies are believed to potentially improve students' learning engagement in promoting their critical speaking skills through daily life storytelling activities. These strategies can attract students to engage in their learning through some opportunities provided by the teachers to convey logical reasons on the basis of comprehensive analysis using the perspectives of Plus (P), Minus (M), and Interesting (I) principles. Students are stimulated to creatively think about ideas development through some relevant exposures created during the learning process. In response to future challenges in $21^{\text {st }}$ century learning, teachers are advised to switch from using conventional learning techniques and strategies to putting more emphasis on the implementation of teacher-centred activities. PMI strategies, as English learning innovations, can be integrated by teachers through several activities such as brainstorming, game playing, role playing, and conducting guided discussions with students. These activities have encouraged students to actively participate in the learning process and teachers, therefore, play their roles as facilitators who guide students to find answers and conclusions from the thinking process experienced in their daily life. They experience holistical learning through class materials and verbally communicate what they have learned to their friends.

PMI strategies are implemented by teachers in stages, and they are accompanied by some strategies and main activities. Through the strategies and activities, teachers can build students' ideas and vocabularies on the topics of discussion by contextually introducing students to daily life stories. The characters in the daily life stories are replaced by the ones chosen by students in order to sharpen students' understanding on PMI strategies by providing critical opinions through the use of diagrams. In addition, PMI strategies are also presented with the use of modified stories intended for students to provide mutual inputs and suggestions on other students' group performances. During the implementation of PMI, however, teachers still find it difficult to implement their professional and pedagogical competencies. From a professional point of view, teachers acknowledge that PMI strategies are very good for improving students' critical thinking skills, particularly in terms of their critical speaking skill. To arrive at this stage, teachers have to be fully prepared to understand both teaching materials and languages used in the topics of their language learning. Difficulties in pedagogical competencies are faced by teachers through various learning scenarios implemented in PMI with relatively new strategies. Therefore, they have to build their optimism through 
continuously implementing PMI strategies and working much harder to achieve success. Teachers are advised to attend regular trainings and workshops to solve their problems towards achieving $21^{\text {st }}$ century language learning goals.

\section{ACKNOWLEDGEMENT}

The researchers would like to extend gratitude and appreciation to the Ministry of Education and Culture of the Republic of Indonesia for the provision of financial support for the completion of this research.

\section{REFERENCES}

Akatsuka, Y. (2019). Awareness of critical thinking attitudes and English speaking skills: The effects of questions involving higher-order thinking. Journal of Pan-Pacific Association of Applied Linguistics, 23(2), 5984.

Al-Khatib, B.A. (2012). The effect of using brainstorming strategy in developing creative problem-solving skills among female students in Princess Alia University College. American International Journal of Contemporary Research, 2(10), 29-38.

Almalki, M.S. (2019). Learning-oriented assessment, critical thinking and English language speaking skills: Exploratory study of Saudi EFL learners. International Journal of English Language Education, 7(1), $37-50$.

Al-Sharadgahm, T. A. (2014). Developing critical thinking skills through writing in an internet-based environment. International Journal of Humanities and Social Science, 1(4), 169-178.

Anderson, L.W., Krathwohl, D.R., Airasian, P.W., Cruikshank, K.A., Mayer, R.E., Pintrich, P.R., Raths, J., \& Wittrock, M.C. (eds). (2001). A taxonomy for learning, teaching, and assessing: A revision of Bloom's taxonomy of educational objectives. Addison Wesley Longman.

Bloom, B. S. (1956). Taxonomy of educational objectives: The classification of education goals. Cognitive domain. Handbook 1. Longman.

Bowman, N. A. (2010). College diversity experiences and cognitive development: A meta-analysis. Review of Educational Research, 80(1), 4-33.

Braun, V. \& Clarke, V. (2006). Using thematic analysis in psychology. Qualitative Research in Psychology, 3(2), 77-101.

Braun, V. \& Clarke, V. (2012). Thematic analysis. In H. Cooper, P. M. Camic, D. L. Long, A. T. Panter, D. Rindskopf, \& K. J. Sher (Eds.), APA handbook of research methods in psychology: Research designs: Quantitative, qualitative, neuropsychological, and biological (Vol. 2, pp. 57-71). American Psychological Association.

Braun, V. \& Clarke, V. (2014). What can "thematic analysis" offer health and wellbeing researchers? International Journal of Qualitative Studies on Health and Wellbeing, 9(1). 10.3402/qhw.v9.26152.

Brookhart, S. M. \& Bronowicz, D. L. (2010). 'I don't like writing. It makes my fingers hurt': Students talk about their classroom assessments. Assessment in Education: Principles, Policy \& Practice, 10(2), 221-242.

Brunner, J. T. (2011). I don't get it! Helping students understand what they read. Rowman \& Littlefield Education.

Burchinal, M. \& Forestieri, N. (2011). Development of early literacy: Evidence from major US longitudinal studies. Handbook of Early Literacy Research, 3, 85-96.

Burns, N., \& Grove, S. K. (2010). Understanding nursing research: Building an evidence-based practice ( $5^{\text {th }}$ ed.). Elsevier-Health Sciences Division.

Cameron, L. (2001). Teaching languages to young learners. Cambridge University Press.

Changwong, K., Sukkamart, A., \& Sisan, B. (2018). Critical thinking skill development: Analysis of a new learning management model for Thai high schools. Journal of International Studies, 11(2), 37-48.

Clarke, V. \& Braun, V. (2013). Teaching thematic analysis: Overcoming challenges and developing strategies for effective learning. The Psychologist, 26(2), 120-123.

Clarke, V. \& Braun, V. (2018). Using thematic analysis in counselling and psychotherapy research: A critical reflection. Counselling and Psychotherapy Research Journal, 18(2), 107-110.

Coffman, D.M. (2013). Thinking about thinking: An exploration of preservice teachers' views about higher order thinking skills. ProQuest LLC.

Creswell, J.W. (2012). Educational research: Planning, conducting, and evaluating quantitative and qualitative research (4 ${ }^{\text {th }}$ ed.). Pearson.

De Bono, E. (1982). De Bono's thinking course. BBC Books.

Emilia, E. (2011). Pendekatan genre-based dalam pengajaran bahasa Inggris: Petunjuk untuk guru (Genre-based approach in the teaching of English: Guidelines for teachers). Rizqi Press. 
Garcia-Corral, F.J., Pablo-Valenciano, J.D., Milan-Garcia, J., \& Cordero-Garcia, J.A. (2020). Complementary currencies: An analysis of the creation process based on sustainable local development principles. Sustainability, 12 (5672), 1-22.

Gay, L.R., Mills, G.E., and Airasian, P. (2006). Educational research: Competencies for analysis and applications. $\left(8^{\text {th }}\right.$ ed). Pearson Education, Inc.

Greiff, S., Wüstenberg, S., Csapó, B., Demetriou, A., Hautamäki, J., Graesser, A. C., \& Martin, R. (2014). Domain-general problem-solving skills and education in the 21 st century. Educational Research Review, $13,74-83$.

Hancock, D.R. \& Algozzine, B. (2006). Doing case study research: A practical guide for beginning researchers. Teachers College Press.

Harizaj, M. \& Hajrulla, V. (2017). Fostering learner's critical thinking skills in EFL: Some practical activities. European Scientific Journal, 13(29), 126-133.

Harklau, L. (2007). The adolescent English language learner: Identities lost and found. In J. Cummins, \& C. Davison (Eds.), International Handbook of English Language Teaching (Vol. 15, pp. 639-653). Springer.

Hasibuan, A. \& Samosir, T.L.P. (2017). The effect of Plus Minus Interesting (PMI) method on students' achievement in writing analytical exposition text: A study at the eleventh grade of students SMK Negeri 1 Padangsidimpuan. Jurnal Education and Development STKIP Tapanuli Selatan, 6(1), 1-6.

Hayes, K. D. \& Devitt, A. A. (2008). Classroom discussions with student-led feedback: A useful activity to enhance development of critical thinking skills. Journal of Food Science Education, 7(4), 65-68.

Hidayat, R.A.U., Gustine, G.G., \& Setyarini, S. (2020). Critical literacy strategy and challenges: Voice from a high school EFL teacher. Jurnal Penelitian Pendidikan (Journal of Educational Research), 20(3), 315324.

Idek, S. \& Othman, N. (2019). Fostering critical thinking skills in ESL reading comprehension through solo questions. International Journal of Management and Applied Science, 5(2), 36-43.

Jianbin, H. \& Jiayan, G. (2010). On communicative competence in curriculum design: A comparison of the college English curriculum requirements and the English curriculum standards. Polyglossia, 18, 73-86.

Kemdikbud. (2013). Kurikulum 2013: Kompetensi dasar Sekolah Menengah Pertama (SMP)/Madrasah Tsanawiyah (MTs) (The 2013 Curriculum: Basic competencies for junior high school). Kementerian Pendidikan dan Kebudayaan (Kemdikbud).

Kiger, M.E. \& Varpio, L. (2020). Thematic analysis of qualitative data: AMEE Guide No. 131. Medical Teacher, 42, 846-854. 10.1080/0142159X.2020.1755030.

King, F.J., Goodson, L., \& Rohani, F. (2010). Higher order thinking skills: Definition, teaching strategies, assessment. Center for Advancement of Learning and Assessment.

Kivunja, C. (2015). Using De Bono's six thinking hats model to teach critical thinking and problem solving skills essential for success in the $21^{\text {st }}$ century economy. Creative Education, 6, 380-391.

Krathwohl, D. R. (2002). A revision of Bloom's taxonomy: An overview. Theory into Practice, 41(4), 212-218.

Kulamikhina, I., Kamysheva, E., Samylova, O., Balobanova, A., \& Rakhmetova, E. (2020). Development of professional communication skills in students in the ESP class: integration of communicative and critical thinking approaches. Advances in Social Science, Education and Humanities Research, 447, 210-215.

Larson, L. C., \& Miller, T. N. (2011). 21st century skills: Prepare students for the future. Phi Delta Kappan, 47(3), 121-123.

Limbach, B., \& Waugh, W. (2010). Developing higher level thinking. Journal of Instructional Pedagogies, 3, 19.

Maguire, M. \& Delahunt, B. (2017). Doing a thematic analysis: A practical, step-by-step guide for learning and teaching scholars. AISHE-J, 8(3), 3351-33514.

Malik, R. S., \& Hamied, F. A. (2016). Research methods: A guide for first time researchers. UPI Press.

Mansfield, G., \& Poppi, F. (2012). The English as a foreign language/lingua franca debate: Sensitising teachers of English as a foreign language towards teaching English as a lingua franca. Profile Issues in Teachers Professional Development, 14(1), 159- 172.

Mirawati \& Amri, Z. (2013). Improving students'speaking ability through PMI (Plus, Minus, and Interesting) strategy at junior high school. Journal of English Language Teaching, 1(2), 216-223.

Nikijuluw, R.C.G.V. \& Puspitasari, D. (2018). The influence of Plus, Minus, and Interesting (PMI) strategy towards students' speaking ability in an Indonesian private secondary school. International Journal of Language Education, 2(2), 113-121.

Pelenkahu, N. (2017). Improving speaking skill through joyful, active, creative, effective approach (JACEA): Classroom action research at fourth grade student. World Journal of English Language, 7(4), 31-44.

Portmann, M. M., \& Easterbrook, S. M. (1992, January). PMI: Knowledge elicitation and De Bono's thinking tools. In Current Developments in Knowledge Acquisition Conference Proceedings, 264-282. Springer.

Puchta, H. (2012). Developing thinking skills in the young learners' classroom. http://www.herbertpuchta.com/wp-content/files_mf/1337014114YL_Thinking_booklet.pdf 
Ramezani, R., Larsari, E.E., \& Kiasi, M.A. (2016). The relationship between critical thinking and EFL learners speaking ability. English Language Teaching, 9(6), 189-198.

Sanpatchayapong, U. (2013). Idea sharing: PMI-A tool for student reflection. PASAA, 46, 179-188.

Sellars, M., Fakirmohammad, R., Bui, L., Fishetti, J., Niyozov, S., Reynolds, R., Thapliyal, N., Liu-Smith, Y.L., \& Ali, N. (2018). Conversations on critical thinking: Can critical thinking find its way forward as the skill set and mindset of the century? Education Sciences, 8(205), 1-29.

Setyarini, S. (2016, October 19-20). Higher order thinking (HOT) in storytelling: An innovative learning model to improve speaking skill of seventh grade students in Bandung [Paper presentation]. The 4th Literary Studies Conference: Children's Literature in Southeast Asia. Universitas Sanata Dharma, Yogyakarta, Indonesia in cooperation with Ateneo de Manila University, the Philippines.

Setyarini, S. \& Narita, F. (2017). Teachers' difficulties and strategies in developing narrative texts as learning materials for young adolescent regarding theme system. Advances in Social Science, Education and Humanities Research, 82, 199-202.

Setyarini, S., Muslim, A. B., Rukmini, D., Yuliasri, I., \& Mujianto, Y. (2018). Thinking critically while storytelling: Improving children's HOTS and English oral competence. Indonesian Journal of Applied Linguistics, 8(1), 189-197. 10.17509/ijal.v8i1.11480.

Setyarini, S., Nurlaelawati, I., \& Putra, R.A.A. (2020). Outdoor education: A contextual English learning activity to improve writing ability of young adolescents. Advances in Social Science, Education and Humanities Research, 430, 188-192.

Sharma, H.L. \& Priyamvada. (2017). PMI (Plus-Minus-Interesting): A creative thinking strategy to foster critical thinking. International Journal of Academic Research and Development, 2(6), 974-977.

Sharma, H.L., Priyamvada., \& Chetna. (2020). PMI (Plus-Minus-Interesting): An attention-directed strategy for enhancing creative thinking among elementary school students. Mukt Shabd Journal, 9(6), 2376-2394.

Spark. (2013). Plus, minus, interesting (PMI). Spark at York University 2013. www.yorku.ca/spark

Stainback, S., \& Stainback, W. (Eds). (1996). Inclusion: A guide for educators. Paul H. Brookes Publishing.

Tarigan, H.G. (2008). Berbicara sebagai suatu keterampilan berbahasa (Speaking as a language skill). Angkasa. Toulmin, S. E. (2003). The uses of argument. Cambridge University Press.

Tuspekova, A., Mustaffa, R. \& Ismail, K. (2020). Understanding English speaking practice in public schools in Kazakhstan: A case study in Almaty. 3L: Language, Linguistics, Literature, 26(1), 171-185.

Tuzlukova, V., Al-Busaidi, S., \& Burns, S.L. (2017). Critical thinking in the language classroom: Teacher beliefs and methods. Pertanika Journal: Social Sciences \& Humanities, 25 (2), 615-634.

Van Merrienboer, J.J.G. (2013). Perspectives on problem solving and instruction. Computers \& Education, 64, 153-160.

Walsh, R.S., McClean, B., Doyle, N., Ryan, S., Scarborough-Lang, S-J., Rishton, A., \& Dagnall, N. (2019). A thematic analysis investigating the impact of positive behavioral support training on the lives of service providers: "It makes you think differently". Frontiers in Psychology, 10(2408), 1-6. 10.3389/fpsyg.2019.02408.

Wang, S., \& Vasquez, C. (2012). Web 2.0 and second language learning: What does the research tell us. Calico Journal, 29(3), 412-430.

Warliati, A.E., Rafli, Z., \& Darmahusni. (2019). Discussion and think pair share strategies on enhancement of EFL students' speaking skill: Does critical thinking matter? Journal of English Language Studies, 4(2), 120-139.

Wilson, K. (2016). Critical reading, critical thinking: Delicate scaffolding in English for academic purposes (EAP). Thinking Skills and Creativity, 22, 256-265.

Xu, Y.J., Kuan, K.J. Rajoo, G.S.R. \& Chua, S.P. (2017). English teachers' perceptions of project-based language learning in secondary schools in China. 3L: Language, Linguistics, Literature, 23(4), 235-250.

Yen, T.S. \& Halili, S. H. (2015). Effective teaching of higher-order thinking (HOT) in education. The Online Journal of Distance Education and E-Learning, 3(2), 41-47.

Yin, R.K. (2018). Case study research and applications: Design and methods. (6 ${ }^{\text {th }}$ ed.). SAGE. 